Estudios de

lingüística inglesa aplicada

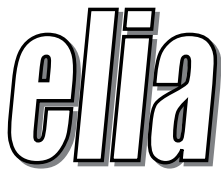

\title{
APPLICABILITY AND VARIATION OF SWALES' CARS MODEL TO APPLIED LINGUISTICS ARTICLE ABSTRACTS
}

\section{LA APLICABILIDAD Y VARIACIÓN DEL MODELO CARS DE SWALES EN RESÚMENES DEARTÍCULOS SOBRE LINGÜÍSTICA APLICADA}

\section{Jorge Alberto Sánchez}

Universidad Nacional de Cuyo, Argentina

jorgealsanchez@hotmail.com

DOI: http://dx.doi.org/10.12795/elia.2018.i18.09

This study examines, from a diachronic-comparative perspective, the applicability and variation of the Create a Research Space (CARS) model to informative abstracts of empirical applied linguistics research articles (RAs) in English published in two high impact academic journals (TESOL Quarterly and Reading Research Quarterly). A pilot study of a smaller sample of 20 abstracts chosen from the 92-abstract corpus published in a twenty-year period (1981-2001) with a five-year interval between each year of publication showed that CARS was applicable to only part of the data and that there were also other rhetorical categories not captured by this framework. The move-step analysis of the 92-abstract corpus indicated that 'Announcing present research', within the move 'Occupying the niche', was the most commonly used step and with the most variation over time. As regards the categories not captured by CARS, it was found that the step 'Drawing conclusions', within the move 'Discussing the research', was

ELIA 18, 2018, pp. 213-240～DOI: http://dx.doi.org/10.12795/elia.2018.i18.09 
employed in almost half of the abstracts of the corpus and it also varied in the years analyzed. The moves 'Occupying the niche' and the sections not captured by CARS, i.e., 'Describing the methodology', 'Summarizing the results', and 'Discussing the research', were the most commonly used and with most variation in the corpus over time. These results suggest that most authors from both journals announce the present research and to inform about the rest of the RA, they include the rhetorical sections 'Describing the methodology', 'Summarizing the results', and 'Discussing the research'.

Key words: informative abstracts, CARS, applied linguistics, moves, steps

Este estudio examina, desde una perspectiva diacrónica-comparativa, la aplicabilidad y variación del modelo CARS en resúmenes informativos de artículos de investigación (AI) empírica en inglés del campo de la lingüística aplicada publicados en dos revistas de alto impacto académico (TESOL Quarterly y Reading Research Quarterly). Un estudio piloto de una muestra más pequeña de 20 resúmenes seleccionados del corpus de 92 resúmenes publicados en un período de veinte años (1981-2001) con intervalos de cinco años entre cada año de publicación mostró que CARS era aplicable sólo a una parte de los datos y que además existían otras secciones retóricas no contempladas por este modelo. El análisis de movimientos y pasos del corpus de 92 resúmenes indicó que el paso más usado y con más variación a lo largo del tiempo fue 'Anunciar la presente investigación' del movimiento 'Ocupar el nicho'. Respecto a las categorías no contempladas por CARS, se encontró que el paso 'Sacar conclusiones', dentro del movimiento 'Discutir la investigación', se usó en casi la mitad de los resúmenes y que este empleo varió en los años analizados. Los movimientos 'Ocupar el nicho'y las secciones no contempladas por CARS, es decir, 'Describir la metodología', 'Resumir los resultados'y 'Discutir la investigación', fueron los más empleados y con más variación en el corpus a lo largo del tiempo. Estos resultados sugieren que la mayoría de los autores de ambas revistas anuncian la presente investigación e incluyen, para informar sobre el resto del AI, las secciones retóricas 'Describir la metodología', 'Resumir los resultados' y 'Discutir la investigación'.

Palabras clave: resúmenes informativos, CARS, lingüística aplicada, movimientos, pasos

ELIA 18, 2018, pp. 213-240～DOI: http://dx.doi.org/10.12795/elia.2018.118.09 


\section{Introduction}

Most of today's scientific knowledge is produced in English. As the top world language or lingua franca for the dissemination of information, nonnative academics and researchers are faced with the challenge of acquiring academic skills in English in order to communicate efficiently the results of their research to intellectuals in international arenas. Publication in journals of international prestige is, therefore, the main route to academic promotion and membership. Most journals specify in their editorial policies that an abstract in English must be attached to all research papers, which must be commonly placed after the title and before the introduction section of the research article (RA).

The RA abstract is an academic discourse genre that performs various functions. The abstract offers preliminary notions about the research, allowing those who wish to read the complete article to examine quickly the content of the paper. The abstract also helps readers retrieve information about aspects of the article that they do not remember from a previous reading. As Lorés (2004) claims "[...] abstracts constitute the gateway that leads readers to take up an article, journals to select contributions, or organizers of conferences to accept or reject papers" (p. 281).

The importance of the abstract as an academic genre for promoting communication and scientific research has generated interest among researchers in applied linguistics, educators, and discourse analysts. The instructions proposed by Cremmins (1982) and Day (1988); the models provided by Graetz (1985) and Weissberg and Buker (1990) and the research carried out by Salager-Meyer (1990a, 1990b), Swales and Feak (1994, 2009), Beke and Bruno de Castelli (2000) and Frydrychova Klimova (2015) offered recommendations for the writing of RA abstracts. Research has also focused on the reading comprehension of the RA abstract genre (Hewings \& Henderson, 198; Hyon, 1996; and Minaabad \& Khoshkholgh, 2012).

Other authors have been interested in the study of the conference abstract and the aspects they have dealt with are of varied nature, such as linguistic features with special reference to purpose, length and audience (Kaplan, Cantor, Hagstrom, Kamhi-Stein, Shiotani, \& Zimmerman, 1994)

ELIA 18, 2018, pp. 213-240～DOI: http://dx.doi.org/10.12795/elia.2018.118.09 
and differences in the rhetorical organization of the conference abstract in English and Spanish in the humanities and the sciences (Bolívar, 1997, 1999; García-Calvo, 1999). Bolívar and Beke (2000) have proposed typologies of the conference abstract according to its functions and the roles of participants in communicative situations. Different instructions have been provided for the writing of the conference abstract in English (Swales \& Feak, 1994, 2000, 2009).

There are also studies dealing with the analysis of the rhetorical organization and/or the occurrence of rhetorical elements as well as the different specific linguistic features of mainly informative applied linguistics abstracts from RAs written in English or in English and Spanish, and published between particular periods of time (Bittencourt dos Santos, 1996; Stotesbury, 2003; Lorés, 2004; Hyland \& Tse, 2005; Pho, 2008; Golebiowski, 2009; Tseng, 2011; Hyland \& Jiang, 2017). However, almost no work has analyzed comparatively and over time, with years of intervals in between, the rhetorical structure of empirical research paper abstracts in English. Gillaerts and Van de Velde (2010, p. 130) examined diachronically interactional metadiscourse in 72 RA abstracts in English from the field of applied linguistics.

The present study is an extension of other works (Bittencourt dos Santos, 1996; Martín-Martín, 2003, and Samraj, 2005) which have either adapted or applied Swales' Create a Research Space (CARS) model (1990, p.141) for the analysis of the introduction section of the abstract in applied linguistics and other fields. Thus, this work aims at examining, from a diachronic-comparative perspective, the applicability and variation of the CARS model to 92 informative applied linguistics abstracts from empirical RAs published in English over a period of twenty years. Basically, this research of 92 abstracts addresses the following main questions:

(i) Is Swales' CARS model applicable to the introduction section of the 92-abstract corpus from a diachronic-comparative perspective?

(ii) How does the use of those rhetorical elements not captured by CARS occur in the 92 abstracts of the corpus over time?

(iii) Is there variation in the 92-abstract corpus as regards the use of the moves and steps proposed by CARS and of those categories not captured by this framework from a diachronic-comparative perspective? 


\section{Theoretical Framework}

\subsection{The Concept of Genre}

For many centuries, the term 'genre' was understood as a synonym of 'literary genre', that is, it was considered that a certain generic status was given to particular written language forms, such as: sonnets, short stories, among others. However, Swales (1981, 1990), Paltridge (2000) and Hyland (2015) developed their notion of genre in academic and research settings and Bhatia (1993) in professional settings. These academics characterized the concept of genre as follows:

a genre is a recognizable communicative event characterized by a set of communicative purpose(s) identified and mutually understood by the members of the professional or academic community in which it regularly occurs (Bhatia, 1993, p. 13; Swales, 1981, pp. 32-36; 1990, pp. 45-64).

genres provide ways of answering current communicative problems; genres are a means in which relevant social knowledge and experiences are transmitted to individuals within a society (Paltridge, 2000, p. 21).

genre is the interface between individuals and communities: the ways that academics who, at the same time as they construct their texts, also construct themselves as competent disciplinary members who have something worthwhile to say (Hyland, 2015, p. 33).

Swales (1990, p. 8) clearly stated that his main concern when writing his book Genre Analysis was to serve the interest of those professionals engaged in the teaching and learning of academic English in first and second language contexts. Swales and other researchers' interest in the application of genre as a pedagogical tool for the teaching and learning of the L1 or L2 texts that students need in their fields of specialization is known as genre-based approach.

\subsection{Genre-based Approach in English for Specific Purposes (ESP)}

Since the mid 80's, researchers and language teachers, especially those concerned with the teaching of ESP, have shown a growing interest in genre-based approaches for analyzing and teaching the spoken and written

ELIA 18, 2018, pp. 213-240～DOI: http://dx.doi.org/10.12795/elia.2018.i18.09 
language required by non-native English speakers in their academic and professional fields (Swales, 1981, 1984, 1990; Hopkins \& Dudley-Evans, 1988; Weissberg \& Buker, 1990, and Bhatia, 1993). Many ESP researchers have focused their attention on explaining the formal aspects and their functional properties or communicative functions of spoken and written genres.

It is important to point out that many ESP scholars, particularly those who have focused their analysis and explanations mainly on the formal characteristics of texts, have resorted to structural move analysis to characterize the rhetorical organizational patterns in different genres, such as experimental research articles (Swales, 1981, 1990), dissertations (Hopkins \& Dudley-Evans, 1988), medical abstracts (Salager-Meyer, 1990a, 1990b), business letters (Bhatia, 1993), and conference abstracts in the humanities and the sciences (Bolívar, 1997, 1999; Beke \& Bruno de Castelli, 2000). Other researchers have shown more interest in describing the linguistic properties or features of these text types, such as tense, voice, and modalization (Graetz, 1985; Swales, 1990; Weissberg \& Buker, 1990; Salager-Meyer, 1992).

Interest in the relationship between form and function in the teaching and learning of writing academic texts is clearly evident in articles and books written by ESP specialists who follow the genre-based approach. Within this area, it is important to mention Bolívar and Beke's (2000) typologies of conference abstracts according to their functions and the roles of the participants in communicative situations. On the other hand, Swales and Feak's $(1994,2000,2009)$ books provide non-native English speaking graduate students with explanations related to the characteristics of different academic genres (conference abstracts, dissertation abstracts, and conference posters, among others). Besides, these books include tasks aimed at assisting these students in the writing process of those genres.

From what has been described so far, the genre-based approach is a useful method which seeks to offer writers an explicit understanding of how texts are structured and why certain forms within these texts transmit particular communicative functions or purposes. Swales (1990) also highlights the importance of employing this method by stating that "a genrecentered approach is likely to focus student attention on rhetorical action and on the organizational and linguistic means of its accomplishment" (p. 82).

ELIA 18, 2018, pp. 213-240～DOI: http://dx.doi.org/10.12795/elia.2018.118.09 


\subsection{Swales' CARS Model}

The theoretical framework of the present study is based on Swales' CARS model of the RA introduction in English. CARS is a communicative model that captures, in its organization, different discourse strategies which are the result of the evidence found on the basis of recurrent rhetorical situations. In this sense, the CARS model transmits knowledge about the socio-cultural context in which it was generated.

In the description of the theoretical approach characterized as genrebased approach, Swales (1990, p. 9) adopts three key concepts: discourse community, genre, and language learning task. Discourse communities are groups of people within a discipline or a particular area of interest which are formed in order to work towards a set of shared rhetorical objectives. These communities share systems of intercommunication among their members through the genres they deal with so as to provide information and feedback (Swales, 1990, pp. 24-26). A genre is a type of communicative event that possesses features of stability and name recognition, and it is characterized by a set of communicative purposes which are identified and understood by the established members of the discourse community (Swales, 1990, pp. 45-58). The work that members of a discourse community are involved in includes the development of tasks which represent specific linguistic, rhetorical, and discourse abilities. Language learning tasks are designed to produce communicative results and consist of a differentiated and sequential set of activities that involve a range of cognitive and communicative procedures related to the effective acquisition of a genre (Swales, 1990, pp. 76).

Within ESP, an important area of influence comes from the work of linguists such as John Swales who recognized the need to assist native and non-native speakers of the English language in reading comprehension and the production of rhetorical styles and discourse types in academic environments. This interest has a practical and pedagogical motivation which is evident in Swales' suggested framework known as the CARS model (1990, p. 141) of the RA introduction (Table 1).

ELIA 18, 2018, pp. 213-240～DOI: http://dx.doi.org/10.12795/elia.2018.i18.09 


\begin{tabular}{|ll|}
\hline Move 1: Establishing a territory & Step 1: Claiming centrality and/or \\
& Step 2: Making topic generalizations and/or \\
& Step 3: Reviewing items of previous research \\
\hline Move 2: Establishing a niche & Step 1A: Counter-claiming or \\
& Step 1B: Indicating a gap or \\
& Step 1C: Question-raising or \\
& Step 1D: Continuing a tradition \\
\hline Move 3: Occupying the niche & Step 1A: Outlining purposes or \\
& Step 1B: Announcing present research \\
& Step 2: Announcing principal findings \\
& Step 3: Indicating research article structure \\
\hline
\end{tabular}

Table 1. Swales' CARS model (1990)

The CARS model represents, through its rhetorical moves, a diversity of characteristics of the RA introduction. These characteristics are related to minor communicative purposes each move performs, such as the need to reestablish in the eyes of the discourse community the importance of the research area, the need to 'situate' the actual research in terms of that importance, and the need to show how this niche or research space will be filled and defended. All these minor communicative purposes contribute to the main communicative intention of the introduction which is that of characterizing the writer in a competition for a research space and for attracting the readers' interest towards the article. Swales (1990) defines the writer's effort for a research space by stating that "[...] the amount of rhetorical work needed to create such a space depends on the existing ecological competition, on the size and importance of the niche to be established, and on various other factors such as the writer's reputation" (p. 142).

\section{Methodology}

\subsection{Context of the Study}

This diachronic-comparative study of the rhetorical or move structure of the abstract according to Swales' CARS model and of the rhetorical categories not captured by this framework is carried out on a corpus of 92

ELIA 18, 2018, pp. 213-240～DOI: http://dx.doi.org/10.12795/elia.2018.118.09 
RA empirical research paper abstracts written in English. The purpose of adopting a diachronic-comparative approach is to determine the applicability of CARS to the introduction section of the 92-abstract corpus, the occurrence of use of the rhetorical sections not captured by CARS, and whether the rhetorical structure of the abstracts remains invariable or exhibits changes per journal and between journals over a span of twenty years. Since researchers like Graetz (1985), Bathia (1993), Bittencourt dos Santos (1996), Hyland (2000), Stotesbury (2003), and Tseng (2011) have investigated informative RA abstracts in the field of applied linguistics and related disciplines, this study also aims to contribute to the body of research that investigates abstracts. Thus, this work extends the research that study the applicability of CARS related to the introduction section in informative abstracts of empirical RAs, contributing to the research carried out by Bittencourt dos Santos (1996), Martin-Martin (2003), and Samraj (2005).

\subsection{Corpus Collection and Selection}

The corpus was drawn from two international journals of high academic impact belonging to the field of applied linguistics: 42 abstracts from TESOL Quarterly (TQ) and 50 abstracts from Reading Research Quarterly (RQ). TQ is the world's most widely read journal for teachers of English as a Second Language and RQ is the world's top journal for research on reading, writing and literacy issues. The main criteria taken into account for the selection of TQ and RQ were their prestige, their longevity as expert resources in the field of applied linguistics research, and also the fact that no other journals available to the researcher published abstracts over a period of twenty years or more.

The abstracts' authors are native speakers or specialists in the English language and the editorial boards of the two journals include experts in the language. These aspects guarantee a relatively high quality of the texts.

The journals include publications such as empirical studies and theoretical articles, among others. In this study, only empirical research paper abstracts were analyzed since the theoretical research paper abstracts were scant or non-existent some years, limiting a diachronic-comparative study.

ELIA 18, 2018, pp. 213-240～DOI: http://dx.doi.org/10.12795/elia.2018.i18.09 
For the purposes of carrying out the diachronic-comparative analysis of the 92-abstract corpus corresponding to the general study, a five-year interval between years of publication in both journals $(1981,1986,1991$, 1996 and 2001) was fixed beforehand and the first ten empirical research paper abstracts in each of these years were selected, with the exception of TQ for the years 1991 and 1996 in which only six empirical studies were published. Thus, the corpus of the present study consists of 92 abstracts, 42 from TQ and 50 from RQ.

\subsection{Procedures for the General Study Corpus}

In this subsection, the procedures related to the general study corpus are specified. The identification of the boundaries between the moves and the steps, interrater reliability, and the conventionality or optionality of the moves and steps were based following the same specifications as in 3.4.

Once the analysis of the rhetorical structure of the general study corpus was completed, the moves and the steps employed in each abstract were counted. This procedure was done for each journal over time in order to search for tendencies as regards the applicability and variation of CARS related to the use of the moves and steps belonging to the abstracts' introduction section, and also the use and variation of those categories not captured by CARS.

As for the qualitative evaluation of the data, this feature was also completed from a diachronic-comparative perspective. The quantitative aspects of this study were limited to the number, average and percentages of the occurrences of the moves and steps.

\subsection{A Pilot Study}

To test the applicability of Swales' CARS model, a smaller sampling of 20 abstracts was chosen from the 92-abstract corpus for a pilot study (10 from TQ and 10 from RQ). From this 20-abstract sample, the first two empirical research paper abstracts from both journals of the years 1981, 1986, 1991, 1996 and 2001 were analyzed.

After identifying the rhetorical structure of the 20-abstract sample, i.e., the moves and steps within each abstract by applying Swales' CARS

ELIA 18, 2018, pp. 213-240～DOI: http://dx.doi.org/10.12795/elia.2018.i18.09 
model, it was found that CARS did not capture all the data found in this sample. The names for the categories not captured by CARS were mainly borrowed from Bittencourt dos Santos's (1996) framework: 'Describing the methodology' (Move 4); 'Summarizing the results'" (Move 5) and 'Discussing the research'2 (Move 6) with its corresponding steps: 'Drawing conclusions' (Step 1A) and/or 'Indicating the implications' (Step 1B) and/ or 'Indicating the applications' (Step 1C). These new categories were numbered following the order proposed by Swales in his CARS model, and as preferred by Santos (personal communication) who has also conducted work on the rhetorical organization or move structure of empirical research paper abstracts in applied linguistics, using the CARS model.

Table 2 shows the rhetorical sections established by the CARS model and the rhetorical categories not captured by this framework. The categories not contemplated by CARS are in bold. It is important to point out that this table was used not only for the analysis of the 20-abstract sample but also for the analysis of the general study corpus.

\begin{tabular}{|ll|}
\hline Move 1: Establishing a territory & $\begin{array}{l}\text { Step 1: Claiming centrality and/or } \\
\text { Step 2: Making topic generalizations and/or } \\
\text { Step 3: Reviewing items of previous research }\end{array}$ \\
\hline Move 2: Establishing a niche & Step 1A: Counter-claiming or \\
& Step 1B: Indicating a gap or \\
& Step 1C: Question-raising or \\
& Step 1D: Continuing a tradition \\
\hline Move 3: Occupying the niche & Step 1A: Outlining purposes or \\
& Step 1B: Announcing present research \\
& Step 2: Announcing principal findings \\
& Step 3: Indicating research article structure \\
\hline Move 4: Describing the methodology \\
\hline Move 5: Summarizing the results \\
\hline Move 6: Discussing the research & Step 1A: Drawing conclusions and/or \\
& Step 1B: Indicating the implications and/or \\
Step 1C: Indicating the applications
\end{tabular}

Table 2. CARS model and the rhetorical sections not captured by CARS

ELIA 18, 2018, pp. 213-240～DOI: http://dx.doi.org/10.12795/elia.2018.i18.09 
The procedure used for the identification of the boundaries between the moves and their corresponding steps of the 20-abstract sample was mainly based on the function or content of the text, i.e, a top-down approach (Pho, 2008, p. 233). After the moves and the steps were identified, the common lexico-grammatical exponents such as metadiscourse phrases ${ }^{3}$, tense, voice, sentence connectors, among others were then analyzed (bottom-up approach).

Once the analysis of the rhetorical structure of the 20-abstract sample was done according to the procedure previously specified, experts were consulted for interrater reliability. Interrater reliability is important in order to establish the validity, consistency, and reliability of the data analysis according to two or more specialists ${ }^{4}$. In this study, rater agreement was reached through discussion among the specialists and the author of this article. To establish if a move and its step are conventional or optional, this study follows Kanoksilapatham's criterion (2005) who stated that if the frequency of a move occurs in $60 \%$ or above, the move is considered a conventional move whereas if the move falls below $60 \%$, then the move is optional.

\section{Results}

In this section, the data as regards the use of the moves and steps of the 92-abstract corpus according to the CARS model and of those categories not captured by this framework are interpreted from a diachroniccomparative perspective. The results obtained in relation to the use of all the steps, without considering those which recurred, corresponding to 'Establishing a territory' (Move 1), 'Establishing a niche' (Move 2), and 'Occupying the niche' (Move 3 ) of the CARS model are comparatively discussed over time (subsections 4.1., 4.2., and 4.3.). The occurrence of use of the rhetorical categories not captured by CARS is informed from a diachronic-comparative perspective in subsection 4.4., particularly; the results about the use of all the steps but not those which recurred within 'Discussing the research' (Move 6). It is important to point out that 'Describing the methodology' (Move 4) and 'Summarizing the results' (Move 5) do not have steps, thus, the use of these non-captured rhetorical elements by CARS will be discussed in sub-section 4.5. The use of 'Establishing a territory', 'Establishing a niche', and 'Occupying

ELIA 18, 2018, pp. 213-240～DOI: http://dx.doi.org/10.12795/elia.2018.i18.09 
the niche' and the rhetorical sections not contemplated by CARS ('Describing the methodology', 'Summarizing the results', and 'Discussing the research'), which considered the recurrence of all the steps and instances, is interpreted from a diachronic-comparative perspective in subsection 4.5.

\subsection{The Use of the Step Options of Move 1 in TQ and RQ over Time}

In some years of publication, the step options 'Claiming centrality', 'Making topic generalizations', and 'Reviewing items of previous research' within Move 1 are absent from TQ, however, these rhetorical elements are seldom used throughout the time period examined (Table 3). In RQ, the occurrences of the different step options corresponding to 'Establishing a territory' (Move 1) display a low use and, like TQ, these categories are not present in some dates of publication. The data as regards the total amount of occurrences per journal indicate that the three-step options within Move 1 seldom appear in the 92 abstract-corpus.

\begin{tabular}{|c|c|c|c|c|c|c|c|c|c|c|c|c|c|c|}
\hline & \multicolumn{7}{|c|}{ TQ } & \multicolumn{7}{|c|}{ RQ } \\
\hline Year & 81 & 86 & 91 & 96 & 01 & & & 81 & 86 & 91 & 96 & 01 & & \\
\hline $\begin{array}{l}\# \\
\text { abs. }\end{array}$ & 10 & 10 & 6 & 6 & 10 & $\begin{array}{c}42 \\
\text { abs. }\end{array}$ & $\%$ & 10 & 10 & 10 & 10 & 10 & $\begin{array}{c}50 \\
\text { abs. }\end{array}$ & $\%$ \\
\hline $\begin{array}{c}11 \\
\text { 'Claiming } \\
\text { Centrality' }\end{array}$ & 1 & 0 & 0 & 1 & 3 & 5 & 12 & 0 & 0 & 1 & 1 & 0 & 2 & 4 \\
\hline $\begin{array}{c}12 \\
\text { 'Making topic } \\
\text { generalizations' }\end{array}$ & 3 & 0 & 1 & 0 & 2 & 6 & 14 & 1 & 1 & 0 & 3 & 1 & 6 & 12 \\
\hline $\begin{array}{c}13 \\
\text { 'Reviewing items } \\
\text { of previous } \\
\text { research' }\end{array}$ & 0 & 1 & 1 & 0 & 2 & 4 & 10 & 2 & 0 & 2 & 3 & 3 & 10 & 20 \\
\hline
\end{tabular}

Table 3. Use of step options of Move 1 in TQ and RQ over time

ELIA 18, 2018, pp. 213-240～DOI: http://dx.doi.org/10.12795/elia.2018.i18.09 
By comparing the data between the two journals, it is observed that, of the 92 abstracts analyzed, 'Claiming centrality' is used in 7 abstracts, 'Making topic generalizations' is employed in 12 abstracts, and 'Reviewing items of previous research' appears in 14 abstracts. Overall, the scant use of the three-step options of Move 1 in the corpus can be attributed to the condensed nature of the abstract genre. Due to space limitations, authors opt to include in the abstracts rhetorical sections or categories of more relevance in order to attract their potential readers' attention to the content of the article. Thus, Swales' CARS model is not applicable in relation to the three-step options of Move 1 from a diachronic-comparative perspective due to the low occurrence of these elements in the ninety-two abstracts examined. The analysis as regards the use of the different rhetorical elements of Move 1 in the 92 abstracts also shows little variation over time (from 0 to 3 instances of steps per year of publication). Considering the percentages of occurrence, the three-step options within Move 1 are optional in the 92 abstract-corpus. These results accorded with Bittencourt dos Santos (1996) who stated that 'Stating current Knowledge' (Move 1-Submove 1A) and 'Citing previous research' (Move 1-Submove 1B) are also optional in his corpus of 94 abstracts from the field of applied linguistics ${ }^{5}$.

\subsection{The Use of the Step Options of Move 2 in TQ and RQ over Time}

The data analysis over time indicates a low use of 'Counter-claiming', 'Indicating a gap', and 'Question-raising'. The rhetorical element 'Continuing a tradition' is a non-existent category in TQ (Table 4). In RQ, 'Counter-claiming', 'Indicating a gap', and 'Question-raising' are seldom used and 'Continuing a tradition' is almost non-existent in the different years of publication. In each journal, the total amount of occurrences for the step options within 'Establishing a niche' (Move 2) shows that 'Counterclaiming', 'Indicating a gap', and 'Question-raising' are seldom employed and that the use of 'Continuing a tradition' is almost absent from the 92-abstract corpus. The comparison of the data between journals displays that, out of the 92 abstracts examined, 'Counter-claiming' appears in only 5 abstracts, 'Indicating a gap' in 13 abstracts, 'Question-raising' in 11 abstracts, and 'Continuing a tradition' in only 1 abstract. Therefore, the low occurrence of 'Counter-claiming', 'Indicating a gap', and 'Questionraising', and the almost non-existence of 'Continuing a tradition' in the

ELIA 18, 2018, pp. 213-240～DOI: http://dx.doi.org/10.12795/elia.2018.118.09 
92-abstract corpus indicate that these categories are optional. In his study, Bittencourt dos Santos (1996) also found that 'Extended previous research' (Move 1-Submove 1C), 'Stating a problem' (Move 1-Submove 2), and 'Hypothesis raising' (Move 2-Submove 2) are also optional elements'.

\begin{tabular}{|c|c|c|c|c|c|c|c|c|c|c|c|c|c|c|}
\hline \multirow[b]{2}{*}{ Year } & \multicolumn{7}{|c|}{ TQ } & \multicolumn{7}{|c|}{ RQ } \\
\hline & 81 & 86 & 91 & 96 & 01 & & & 81 & 86 & 91 & 96 & 01 & & \\
\hline $\begin{array}{l}\# \\
\text { abs. }\end{array}$ & 10 & 10 & 6 & 6 & 10 & $\begin{array}{l}4 L \\
\text { abs. }\end{array}$ & $\%$ & 10 & 10 & 10 & 10 & 10 & abs. & $\%$ \\
\hline $\begin{array}{c}21 \mathrm{~A} \\
\text { 'Counter- } \\
\text { claiming' }\end{array}$ & 1 & 0 & 0 & 0 & 1 & 2 & 5 & 0 & 0 & 0 & 0 & 3 & 3 & 6 \\
\hline $\begin{array}{c}21 \mathrm{~B} \\
\text { 'Indicating a gap' }\end{array}$ & 1 & 0 & 1 & 2 & 4 & 8 & 19 & 0 & 0 & 1 & 2 & 2 & 5 & 10 \\
\hline $\begin{array}{c}21 \mathrm{C} \\
\text { 'Question-raising' }\end{array}$ & 0 & 1 & 2 & 1 & 1 & 5 & 12 & 0 & 1 & 1 & 3 & 1 & 6 & 12 \\
\hline $\begin{array}{c}21 \mathrm{D} \\
\text { 'Continuing a } \\
\text { tradition' }\end{array}$ & 0 & 0 & 0 & 0 & 0 & 0 & 0 & 0 & 0 & 0 & 1 & 0 & 1 & 2 \\
\hline
\end{tabular}

Table 4. Use of step options of Move 2 in TQ and RQ over time

As pointed out for the different step options for Move 1, the fact that 'Counter-claiming', 'Indicating a gap', and 'Question-raising' are of low use and that 'Continuing a tradition' is almost non-existent in the 92 abstracts can be related to the fact that the abstract is a reduced text and authors need to include more relevant rhetorical categories. Thus, Swales' framework is not applicable to the different rhetorical elements which are characteristic of Move 2. The data also shows that there is little variation in the use of 'Counter-claiming', 'Indicating a gap', and 'Question-raising' in the corpus over time (from 0 to 4 instances of steps per year). Almost no variation is found in the use of 'Continuing a tradition' in the 92 abstracts in the time period examined (from 0 to 1 occurrence of step per year of publication). 


\subsection{The Use of the Step Options of Move 3 in TQ and RQ over Time}

As regards the different step options of 'Occupying the niche' (Move 3) in TQ, the data over time and the total amount of occurrences show a low use (4/42 abstracts) of 'Outlining purposes' (Table 5). The rhetorical sections 'Announcing principal findings' and 'Indicating research article structure' are non-existent. However, the use of 'Announcing present research' is high (32/42 abstracts $-76 \%)$ in four of the five years of publication examined, thus, being the most commonly occurring rhetorical element. According to the different years of publication and the total number of occurrences, 'Outlining purposes', in RQ, is used in 6 of the 10 abstracts examined in the year 1981; however, this usage lowers in the following years of publication. In contrast to TQ, there are 15 total occurrences of 'Outlining purposes' in the 50 abstracts examined (30\%). 'Announcing principal findings' is nonexistent and 'Indicating research article structure' is present in only 1 abstract. The rhetorical element 'Announcing present research' is commonly used over time, appearing in 40 of the 50 abstracts examined, with a total percentage slightly higher for RQ $(80 \%)$ than for TQ $(76 \%)$.

\begin{tabular}{|c|c|c|c|c|c|c|c|c|c|c|c|c|c|c|}
\cline { 2 - 13 } \multicolumn{1}{c|}{} & \multicolumn{9}{c|}{ TQ } & \multicolumn{7}{c|}{ RQ } \\
\hline Year & 81 & 86 & 91 & 96 & 01 & 42 & & 81 & 86 & 91 & 96 & 01 & & \\
\cline { 1 - 14 } \\
abs. & 10 & 10 & 6 & 6 & 10 & abs. & $\%$ & 10 & 10 & 10 & 10 & 10 & abs. & $\%$ \\
\hline $\begin{array}{c}31 \text { A } \\
\text { 'Outlining purposes' }\end{array}$ & 0 & 2 & 1 & 0 & 1 & 4 & 10 & 6 & 1 & 4 & 2 & 2 & 15 & 30 \\
\hline $\begin{array}{c}31 \text { B } \\
\text { 'Announcing present } \\
\text { research' }\end{array}$ & 3 & 9 & 5 & 5 & 10 & 32 & 76 & 8 & 6 & 7 & 10 & 9 & 40 & 80 \\
\hline $\begin{array}{c}32 \\
\text { 'Announcing principal } \\
\text { findings' }\end{array}$ & 0 & 0 & 0 & 0 & 0 & 0 & 0 & 0 & 0 & 0 & 0 & 0 & 0 & 0 \\
\hline $\begin{array}{c}33 \\
\text { 'Indicating research } \\
\text { article structure' }\end{array}$ & 0 & 0 & 0 & 0 & 0 & 0 & 0 & 0 & 0 & 1 & 0 & 0 & 1 & 2 \\
\hline
\end{tabular}

Table 5. Use of step options of Move 3 in TQ and RQ over time

ELIA 18, 2018, pp. 213-240～DOI: http://dx.doi.org/10.12795/elia.2018.i18.09 
Data comparison between journals shows that of the 92 abstractcorpus, 'Announcing present research' occurs in 72 abstracts, 'Outlining purposes' appears in 19 abstracts, 'Announcing principal findings' is completely absent and 'Indicating research article structure' is employed in only 1 abstract . This evidence indicates that 'Announcing present research' is a conventional element in the corpus while the other step options within Move 3 are optional. Some of these results are in line with those of Bittencourt dos Santos (1996) who pointed out that 'Indicating main features' (Move 2-Submove 1A) is obligatory or conventional (77/ 94 abstracts) and 'Indicating main purpose' (Move 2-Submove 1B) is an optional category?

Based on the preceding results, it can be said that 'Announcing present research' plays an important role in the 92 abstract-corpus in contrast to the other rhetorical categories which are seldom used 'Outlining purposes', non-existent 'Announcing principal findings' or almost completely absent 'Indicating research article structure'. These features may be related, as it has already been pointed out for the different step options for Move 1 and Move 2, to the fact that the abstract is a reduced text and, therefore, there is not enough space for the inclusion of most of the rhetorical elements which are characteristic of Move 3. On the basis of all these observations, Swales' CARS model is not applicable to some of the step options of Move 3 with the exception of 'Announcing present research'.

The data also show that there is little variation in the use of 'Outlining purposes' (from 0 to 6 occurrences of steps); however, 'Announcing present research' has varied in the 92 abstracts in the different years of publication (from 3 to 10 occurrences of steps). As regards 'Indicating research article structure', almost no variation is found (from 0 to 1 occurrence of step per year) and in relation to the rhetorical element 'Announcing principal findings', no variation is observed in the 92 abstracts in the different years of publication examined.

\subsection{The Use of the Step Options of Move 6 in TQ and RQ over Time}

As for the non-captured rhetorical sections by CARS, the data over time and the total amount of instances of steps within 'Discussing the research'

ELIA 18, 2018, pp. 213-240～DOI: http://dx.doi.org/10.12795/elia.2018.118.09 
(Move 6) in TQ show that 'Drawing conclusions' is employed in half of the abstracts in 1981, 1991, and 2001 whereas it appears in 4 of the 10 abstracts in 1986 and in 4 of the 6 abstracts in 1996 (Table 6). Thus, this structural element presents a medium occurrence of use (21/42 abstracts), appearing in $50 \%$ of the TQ abstracts. Less use is observed for 'Indicating the implications' over time than that for 'Drawing conclusions'. 'Indicating the implications' is present in 3 of the 10 abstracts in 1981 and 1986 and there are 2 occurrences of this category in 1996 and 2001. In 1991, only 1 abstract employs this rhetorical element. This rhetorical category occurs in 11 out of the 42 abstracts (26\%). The use of 'Indicating the applications' in TQ is scant since it appears in only 1 abstract in each of the years examined $(5 / 42$ abstracts $-12 \%)$.

\begin{tabular}{|c|c|c|c|c|c|c|c|c|c|c|c|c|c|c|}
\hline & \multicolumn{7}{|c|}{ TQ } & \multicolumn{7}{|c|}{ RQ } \\
\hline Year & 81 & 86 & 91 & 96 & 01 & & & 81 & 86 & 91 & 96 & 01 & & \\
\hline \begin{tabular}{|l}
$\#$ \\
abs.
\end{tabular} & 10 & 10 & 6 & 6 & 10 & $\begin{array}{l}42 \\
\text { abs. }\end{array}$ & $\%$ & 10 & 10 & 10 & 10 & 10 & $\begin{array}{c}50 \\
\text { abs. }\end{array}$ & $\%$ \\
\hline $\begin{array}{c}61 \mathrm{~A} \\
\text { 'Drawing } \\
\text { conclusions' }\end{array}$ & 5 & 4 & 3 & 4 & 5 & 21 & 50 & 5 & 5 & 7 & 2 & 5 & 24 & 48 \\
\hline $\begin{array}{l}\text { 61B } \\
\text { 'Indicating the } \\
\text { implications' }\end{array}$ & 3 & 3 & 1 & 2 & 2 & 11 & 26 & 2 & 3 & 1 & 3 & 3 & 12 & 24 \\
\hline $\begin{array}{l}61 \mathrm{C} \\
\text { 'Indicating the } \\
\text { applications' }\end{array}$ & 1 & 1 & 1 & 1 & 1 & 5 & 12 & 3 & 0 & 1 & 0 & 0 & 4 & 8 \\
\hline
\end{tabular}

Table 6. Use of step options of Move 6 in TQ and RQ over time

Like TQ, 'Drawing conclusions' exhibits a medium occurrence of use in RQ in three years of publication $(1981,1986$, and 2001) since 5 of the 10 abstracts analyzed in each of these years contain this element. In 1991, 'Drawing conclusions' occurs in 7 of the 10 abstracts examined and, therefore, it presents the highest use among the years analyzed. In contrast, of the 10 abstracts in 1996, only 2 include this rhetorical element. The total 
amount of instances shows that 'Drawing conclusions' is almost of medium use in RQ (24/50 abstracts, $48 \%$ ). Less use is observed for 'Indicating the implications' in the different years of publication examined since it is employed in 3 of the 10 abstracts in each of the following years: 1986, 1996, and 2001. This element is present in 2 abstracts of 1981 and in 1 of 1991. On average, 'Indicating the implications' appears in $24 \%$ of the abstracts from RQ (12/50 abstracts).The data over time show that 'Indicating the applications' is seldom used in 1981 and it is almost non-existent in 1991. In the other years analyzed, this category is totally absent. This element occurs in $8 \%$ of the abstracts from RQ (4/50 abstracts).

Compared to the instances found for each of the step options of 'Establishing a territory' (Move 1) and 'Establishing a niche' (Move 2) as well as for the categories 'Outlining purposes', 'Announcing principal findings', and 'Indicating research article structure' corresponding to 'Occupying the niche' (Move 3), 'Drawing conclusions' occurs in almost half of the corpus (45/92 abstracts). This shows that TQ and RQ authors tend to offer a general explanation of what the findings mean in their abstracts (50\% and $48 \%$, respectively). As regards 'Indicating the implications' and 'Indicating the applications', the data clearly exhibit less preference for the inclusion of these elements in the 92 abstracts (23 and 9 abstracts respectively) ${ }^{8}$. Within Move 6, 'Drawing conclusions' is an optional category like the other step options corresponding to this move. Bittencourt dos Santos (1996) also stated that Move 5-Submove 1 'Drawing conclusions' is an optional category in his corpus (50/94 abstracts). It is important to point out that, in the present study, variation is also observed as regards the use of 'Drawing conclusions' in the 92-abstract corpus (from 2 to 7 occurrences of step per year) in contrast to the little variation for 'Indicating the implications' (from 1 to 3 occurrences of steps per year of publication) or the almost no variation found for 'Indicating the applications' (from 0 to 3 occurrences of steps over time).

\subsection{The Use of Moves 1, 2, and 3 and the Rhetorical Sections not Captured by CARS (Moves 4, 5, and 6)}

As can be seen in Table 7, the most commonly used moves in the 92-abstract corpus are Move 4 'Describing the methodology', Move 3 'Occupying the niche', and Move 5 'Summarizing the results'. 'Describing the 
methodology', a rhetorical category not captured by CARS, is the first most included element by TQ and RQ's authors, which is represented by 119 instances $(24.38 \%)$ of the total amount of steps and instances $(N=488)$. Thus, this move is a conventional category in the corpus and this accords with Bittencourt dos Santos's (1996), Pho's (2008) and Tseng's (2011) findings which indicated that Move 3, 'Describing the methodology' or 'Method', is a conventional move in their applied linguistics corpus. It is also important to highlight that, in this study, there is variation in the total amount of instances of 'Describing the methodology' in the 92-abstract corpus over time (ranging from 20 to 27 total amount of instances).

The second most common rhetorical element is 'Occupying the niche', accounting for 118 steps of the total number of steps and instances $(24.18 \%)$ in the 92 abstracts. This element is, therefore, the most employed element of the three move types established by the CARS model. Based on these observations, this move is also a conventional category in the 92-abstract corpus and this is in line with Bittencourt dos Santos's (1996), Pho's (2008) and Tseng's (2011) analysis which showed that Move 2, 'Presenting the research' or 'Aim', is also a conventional element in their corpus. Variation is also observed in the total number of steps of 'Occupying the niche' in the 92 abstracts in the twenty years examined (ranging from 20 to 30 total number of steps).

'Summarizing the results', another category not contemplated by Swales' framework, is the third most included category in the 92-abstract corpus, represented by 104 instances of the total number of steps and instances in the corpus $(21.31 \%)$. In other words, communicating the main findings of the study plays an important role and, thus, this element is also a conventional move in the 92 abstracts. This result accords with Bittencourt dos Santos's (1996), Pho's (2008) and Tseng's (2011) observations which indicated that Move 4, 'Summarizing the results', 'Summarizing the findings' or 'Results', is a conventional category in their studies. Another interesting feature found in this study is related to the fact that 'Summarizing the results' has also varied in the 92-abstract corpus over time (ranging from 19 to 24 total amount of instances).

'Discussing the research', another not captured category by the CARS Model, is less employed than 'Occupying the niche', 'Describing 


\begin{tabular}{|c|c|c|c|c|c|c|c|c|}
\hline \multirow{2}{*}{\multicolumn{2}{|c|}{ Year }} & \multicolumn{5}{|c|}{ Total $\mathrm{N}^{0}$ of steps and instances in } & \multirow{2}{*}{$\begin{array}{l}\text { Total } N^{0} \text { of steps } \\
\text { and instances } \\
\text { in each Move }\end{array}$} & \multirow{3}{*}{$\%$} \\
\hline & & 1981 & 1986 & 1991 & 1996 & 2001 & & \\
\hline \multicolumn{2}{|c|}{$\mathrm{N}^{0}$ of abs. } & 20 & 20 & 16 & 16 & 20 & 92 & \\
\hline \multirow[t]{2}{*}{ M } & $\begin{array}{c}1 \\
\text { 'Establishing a } \\
\text { territory' }\end{array}$ & 8 & 2 & 5 & 8 & 13 & 36 & 7.37 \\
\hline & $\begin{array}{c}2 \\
\text { 'Establishing a } \\
\text { niche' }\end{array}$ & 4 & 2 & 5 & 10 & 12 & 33 & 6.76 \\
\hline 0 & $\begin{array}{l}3 \\
\text { 'Occupying } \\
\text { the niche' }\end{array}$ & 20 & 24 & 22 & 22 & 30 & 118 & 24.18 \\
\hline V & $\begin{array}{c}4 \\
\text { 'Describing } \\
\text { the } \\
\text { methodology' }\end{array}$ & 27 & 25 & 20 & 21 & 26 & 119 & 24.38 \\
\hline $\mathrm{E}$ & $\begin{array}{c}5 \\
\text { 'Summarizing } \\
\text { the results' }\end{array}$ & 24 & 20 & 19 & 19 & 22 & 104 & 21.31 \\
\hline S & $\begin{array}{c}6 \\
\text { 'Discussing } \\
\text { the research' }\end{array}$ & 19 & 16 & 15 & 12 & 16 & 78 & 15.98 \\
\hline
\end{tabular}

Table 7. Use of moves 1, 2 and 3 and the rhetorical moves not captured by CARS

the methodology', and 'Summarizing the results' in the 92 abstracts, with 78 steps, or $15.98 \%$ of the total, still doubling the total number of steps found for 'Establishing a territory' and 'Establishing a niche' (36 and 33 steps, respectively). Therefore, by considering the total amount of steps of 'Discussing the research', this move is a conventional element in the 92-abstract corpus and this is in agreement with Bittencourt dos Santos's (1996), Pho's (2008) and Tseng's (2011) studies which reported that Move 5, 'Discussing the research' or 'Conclusion', is a conventional category in their corpus. In this study, there is also variation as regards the use of 
'Discussing the research' in the 92 abstracts in the years of publication examined (ranging from 12 to 19 total number of steps).

As for the other two moves corresponding to the CARS model, little use is observed for 'Establishing a territory' and 'Establishing a niche' in the 92-abstract corpus. The data which show the total amount of steps representing each of these moves indicate that 'Establishing a territory' and 'Establishing a niche' are the least occurring moves $(7.37 \%$ and $6.76 \%$, respectively) and, therefore, they are optional categories in the 92 abstracts 9 The analysis also reveals that there is variation in the total amount of steps of 'Establishing a territory' and 'Establishing a niche' in the corpus in the time period analyzed (ranging from 2 to 13 total number of steps).

\section{Conclusions}

This study has analyzed the applicability and variation of Swales' CARS model to 92 informative applied linguistics abstracts from empirical RAs in English. Different aspects resulting from this analysis are addressed in the different research questions of the present study.

The first research question asks whether Swales' CARS model is applicable to the introduction section of the 92-abstract corpus from a diachronic-comparative perspective. The analysis as regards the use of all the steps, but not those which recurred, within each of the moves of the CARS model, indicated that the step option 'Announcing present research', within 'Occupying the niche' (Move 3), was the most commonly occurring step and a conventional one in the 92 abstracts. The rest of the steps specified in the CARS model were of low use, non-existent or almost nonexistent. As for the analysis of the use of the three moves established by CARS, which considered the recurrence of steps, it was found that 'Establishing a territory' (Move 1) and 'Establishing a niche' (Move 2) were the least employed and, thus, they were optional elements in the corpus. However, 'Occupying the niche' (Move 3) was the most commonly employed move and a conventional or obligatory element in the corpus. Thus, based on the occurrence of use, Swales' CARS model is not completely applicable to the introduction section of the 92-abstract corpus from a diachronic-comparative perspective since this framework was only

ELIA 18, 2018, pp. 213-240～DOI: http://dx.doi.org/10.12795/elia.2018.i18.09 
applicable to the step 'Announcing present research' and to only one move, i.e., 'Occupying the niche'.

The second research question enquires how the use of those rhetorical elements not captured by CARS occurs in the 92 abstracts of the corpus over time. The analysis of the usage of all the steps within 'Discussing the research' (Move 6), except those which were repeated, showed that 'Drawing conclusions' appeared in approximately half of the abstracts in the corpus, illustrating the tendency for authors to include this rhetorical category in their abstracts. Still, the analysis showed that 'Indicating the implications' and 'Indicating the applications' were used less commonly than 'Drawing conclusions' in the 92 abstracts. These results also indicated that all the step options within 'Discussing the research' were optional elements in the corpus. On the other hand, the use of the moves not captured by CARS (i.e. 'Describing the methodology'(Move 4), 'Summarizing the results' (Move 5), and 'Discussing the research'(Move 6), which considered the repetition of steps and instances, indicated that, these rhetorical moves were the most commonly employed elements and conventional ones in the 92-abstract corpus.

As stated in the preceding paragraphs, it can be said that most TQ and RQ authors employ a rhetorical step 'Announcing present research' which belongs to 'Occupying the niche' (Move 3) of Swales' CARS model. Along with this element, authors, in their efforts to capture their readership, also condense in their abstracts the most salient information corresponding to the rest of the rhetorical sections of their empirical RAs, i.e., the categories 'Describing the methodology', 'Summarizing the results' and 'Discussing the research'.

The third research question asks if there is variation in the 92-abstract corpus as regards the use of the moves and steps proposed by CARS and of those categories not captured by this framework from a diachroniccomparative perspective. The analysis reveals that, based on the occurrence of use, the only step option that varied most in the corpus over the twenty years examined was 'Announcing present research'. As for the rest of the step options within 'Establishing a territory', 'Establishing a niche', and 'Occupying the niche', it was observed little, almost no variation or no variation at all. In relation to the rhetorical categories not captured by CARS, the data over time also revealed that there was variation in the use

ELIA 18, 2018, pp. 213-240 DOI: http://dx.doi.org/10.12795/elia.2018.i18.09 
of 'Drawing conclusions' whereas 'Indicating the implications' varied little in each of the years analyzed. Almost no variation was found for 'Indicating the applications'. On the other hand, as regards the moves, it was observed that 'Occupying the niche', Describing the methodology', 'Summarizing the results', and 'Discussing the research' exhibited more variation in the corpus in the twenty years examined. However, 'Establishing a territory' and 'Establishing a niche' showed less variation in the 92 abstracts over the time period examined.

Finally, since this work has examined informative abstracts of empirical applied linguistics RAs in English from a diachronic-comparative perspective, its results may contribute to the evolving or dynamic nature of academic genres. Besides, this study may also shed light on the teaching and learning of informative applied linguistics abstracts from empirical RAs in English within ESP and English for Academic Purposes (EAP) courses. This latter aspect can be accomplished by designing reading and writing tasks in order to raise non-native English speaking students' awareness of the rhetorical structure, the lexico-grammatical elements and other aspects which are characteristic of the abstract genre.

\section{Notes}

1 This section is not comparable to the category 'Announcing principal findings' of the CARS model since the results section included in the abstracts of the corpus represents a more extensive summary of the main findings of the research.

2 This term refers to the fact that the researcher is in a position to advance the significance of his/her work, i.e., to make claims based on the results obtained.

${ }^{3}$ As Swales \& Feak (2000) state "metadiscourse phrases enable the author to intrude into his or her text $[\ldots]$ in order to direct or engage the readers in some way" (pp. 169-170).

${ }^{4}$ The three experts consulted are native speakers of the English language: John Swales and Christine Feak (University of Michigan) and Paul Chandler (University of Hawaii).

${ }^{5}$ In his framework, particularly for 'Establishing a territory' and 'Establishing a niche', Bittencourt dos Santos adapted Swales' CARS Model where Move

ELIA 18, 2018, pp. 213-240～DOI: http://dx.doi.org/10.12795/elia.2018.i18.09 
1-Submove 1A 'Stating current knowledge' corresponds to CARS Move 1-Step 1 'Claiming centrality' and Move 1- Step 2 'Making topic generalizations' whereas Move 1-Submove 1B 'Citing previous research' correlates with Move 1-Step 3 'Reviewing items of previous research' of the CARS model.

${ }^{6}$ Bittencourt dos Santos's Move 1-Submove 1C 'Extended previous research' correlates with Move 2-Step 1D 'Continuing a tradition' of the CARS model, Move 1-Submove 2 'Stating a problem' corresponds to CARS Move 2-Step 1B 'Indicating a gap' and Move 2-Submove 2 'Hypothesis raising' corresponds to CARS Move 2-Step 1C 'Question raising' of the CARS Model.

7 Bittencourt dos Santos' Move 2-Submove 1A 'Indicating main features' corresponds to CARS Move 3-Step 1B 'Announcing present research' and Move 2-Submove 1B 'Indicating main purpose' correlates with Move 3- Step 1A 'Outlining purposes' of Swales' CARS Model.

${ }^{8}$ In his framework, Bittencourt dos Santos did not include categories similar to 'Indicating the implications' or 'Indicating the applications' as suggested in the present study.

${ }^{9}$ In this study, no reference can be done in relation to what other studies have found in terms of whether 'Establishing a territory' and 'Establishing a niche' are conventional/obligatory or optional since these moves are merged into one move in studies related to informative applied linguistics abstracts.

\section{References}

Bhatia, V. K. (1993). Analysing genre: Language use in professional settings. London: Longman.

Beke, R., \& Bruno de Castelli, E. (2000). El Uso de Estrategias para la Elaboración de Resúmenes de Textos en el Ámbito Académico. Boletín de Lingüística. 15, 19-35.

Bittencourt dos Santos, M. (1996). The textual organization of research paper abstracts in applied linguistics. Text, 16, 4, 481-499.

Bolívar, A. (1997). La Pragmática Lingüística de los Resúmenes de Investigación para Congresos. Boletín de Lingüistica, 12-13, 153-173.

Bolívar, A. (1999). Homogeneidad versus Variedad en la Estructura de los Resúmenes de Investigación para Congresos. Akademos, 2, 121-138.

ELIA 18, 2018, pp. 213-240～DOI: http://dx.doi.org/10.12795/elia.2018.i18.09 
Bolívar, A., \& Beke, R. (2000). El Discurso Académico en Inglés para Investigadores en Humanidades: El Caso de los Abstracts. Cuadernos Lengua y Habla, 2, 95-119.

Cremmins, E. T. (1982). The art of abstracting. Philadelphia: ISI Press.

Day, R. (1988). How to write and publish a scientific paper. U.S.A.: The Oryx Press.

Frydrychova Klimova, B. (2015). Teaching English abstract writing effectively. Procedia - Social and Behavioral Sciences, 186, 908-912. https://doi. org/10.1016/j.sbspro.2015.04.113

García-Calvo, J. (1999). Un Estudio Comparativo de Abstracts para Eventos Científicos en Inglés y Español. D.E.L.T.A., 15, 2, 269-288.

Gillaerts, P., \& Van de Velde, F. (2010). Interactional metadiscourse in research article abstracts. Journal of English for Academic Purposes. 9, 128-139. https://doi.org/10.1016/j.jeap.2010.02.004

Golebiowski, Z. (2009). Prominent messages in Education and Applied Linguistic abstracts: How do authors appeal to their prospective readers? Journal of Pragmatics 41, 753-769. https://doi.org/10.1016/j.pragma.2008.10.009

Graetz, N. (1985). Teaching EFL Students to Extract Structural Information from Abstracts. In J.M. Uljin \& A. K. Pugh (Eds.) Reading for Professional Purposes. Methods and Materials in Teaching Languages. (pp. 1-22). Lauven: ACCO.

Hewings, A., \& Henderson, W. (1987). A link between genre and schema. A case study of Birmingham. English Language Research Journal, 1, 459-467.

Hopkins, A., \& Dudley-Evans, T. (1988). A Genre-Based Investigation of the Discussion Sections in Articles and Dissertations. English for Specific Purposes, 7, 112-121.

Hyland, K. (2000). Disciplinary discourses. London: Longman.

Hyland, K., \& Tse, P. (2005). Hooking the reader: a corpus study of evaluative that in abstracts. English for Specific Purposes, 24, 123-139. https://doi. org/10.1016/j.esp.2004.02.002

Hyland, K. (2015). Genre, discipline and identity. Journal of English for Academic Purposes, 19, 32-43. https://doi.org/10.1016/j.jeap.2015.02.005

ELIA 18, 2018, pp. 213-240～DOI: http://dx.doi.org/10.12795/elia.2018.i18.09 
Hyland, K., \& Jiang, F. (2017). Metadiscursive nouns: Interaction and cohesion in abstract moves. English for Specific Purposes, 46, 1-14. https://doi. org/10.1016/j.esp.2016.11.001.

Hyon, S. (1996). Genre in three traditions: Implications for TESL. TESOL Quarterly, 4, 693-720. https://doi.org/10.2307/3587930

Kanoksilapatham, B. (2005). Rhetorical studies of biochemistry research articles. English for Specific Purposes, 24, 269-292. https://doi.org/10.1016/j. esp.2004.08.003

Kaplan, R., Cantor, S., Hagstrom, C., Kamhi-Stein, L., Shiotani, Y., \& Zimmerman, C. (1994). On Abstract Writing. Text, 14, 3, 401-426.

Lorés, R. (2004). On RA abstracts: from rhetorical structure to thematic organization. English for Specific Purposes, 23, 2, 280-302. https://doi. org/10.1016/j.esp.2003.06.001

Martín-Martín, P. (2003). A genre analysis of English and Spanish research paper abstracts in experimental social sciences. English for Specific Purposes, 22, $25-43$.

Minaabad, M., \& Khoshkholgh, F. (2012). Investigating the effect of genre based pedagogy on English for Specific Purpose learners' reading comprehension. World Applied Sciences Journal, 2, 251-260.

Paltridge, B. (2000). Making sense of discourse analysis. Gold Coast, Queensland: Antipodean Educational Enterprises.

Pho, P. (2008). Research article abstracts in applied linguistics and educational technology: a study of linguistic realizations of rhetorical structure and authorial stance. Discourse Studies, 10, 2, 231-250. https://doi. org/10.1177/1461445607087010

Salager-Meyer, F. (1990a). Discoursal movements in medical English abstracts and their linguistic exponents: A genre analysis study. Interface, 4, 107124.

Salager-Meyer, F. (1990b). Discoursal flaws in medical English abstracts: A genre analysis per research type- and text-type. Text, 10, 365-384. https://doi. org/10.1515/text.1.1990.10.4.365

ELIA 18, 2018, pp. 213-240～DOI: http://dx.doi.org/10.12795/elia.2018.i18.09 
Salager-Meyer, F. (1992). A text-type and move analysis study of verb tense and modality distribution in medical English abstracts. English for Specific Purposes, 11, 93-113. https://doi.org/10.1016/S0889-4906(05)80002-X

Samraj, B. (2005). An exploration of a genre set: Research article abstracts and introductions in two disciplines. English for Specific Purposes, 24, 141156. https://doi.org/10.1016/j.esp.2002.10.001

Stotesbury, H. (2003). Evaluation in research article abstracts in the narrative and hard sciences. Journal of English for Academic Purposes, 2, 327-341. https://doi.org/10.1016/S1475-1585(03)00049-3

Swales, J. (1981). Aspects of article introductions. Birmingham: The University of Aston.

Swales, J. (1984). Research into the structure of introductions to journal articles and its application to the teaching of academic writing. In R. Williams \& J. Swales (Eds.), ELT documents (pp. 77-86).

Swales, J. (1990). Genre analysis. English in academic and research settings. Birmingham: Cambridge University Press.

Swales, J., \& Feak, C. (1994). Academic writing for graduate students. A course for nonnative speakers of English. Michigan: The University of Michigan Press.

Swales, J., \& Feak, C. (2000). English in today's research world: A writing guide. Michigan: The University of Michigan Press.

Swales, J., \& Feak, C. (2009). Abstracts and the writing of abstracts. Michigan: The University of Michigan Press.

Tseng, F. (2011). Analyses of move structure and verb tense of research article abstracts in applied linguistics journals. International Journal of English Linguistics, 1, 2, 27-39. http://dx.doi.org/10.5539/ijel.v1n2p27

Weissberg, R., \& Buker, S. (1990). Writing up research. Experimental research report writing for students of English. Englewood Cliffs, NJ: Printice Hall Regents.

First version received: July, 2018

Final version accepted: September, 2018

ELIA 18, 2018, pp. 213-240～DOI: http://dx.doi.org/10.12795/elia.2018.i18.09 